\title{
Human Rights Protection on Determination for the Suspect of Corruption Crimes
}

\author{
Makkah HM$^{1} \quad$ M. Syukri Akub ${ }^{2}$ Andi Muhammad Sofyan ${ }^{2} \quad$ Hamzah Halim $^{2}$ \\ 1.Graduate School, Hasanuddin University, Indonesia \\ 2.Professor, Faculty of Law, Hasanuddin University, Indonesia
}

\begin{abstract}
The pre-trial concept in Indonesia was inspired by commissioner judges in European countries. Basically, a pretrial application is submitted to the court, if there are rights violated. The right to file a pretrial is owned by a suspect or victim, his family, or other authorized parties, investigators and prosecutors, and third parties. Cases that can be applied for pretrial include whether or not the arrest and or detention is valid, whether or not the termination of the investigation or termination of the prosecution, the request for compensation and rehabilitation are valid or not. The judicial process in Indonesia is based on Pancasila, which places human dignity and dignity in its place and implements human rights protection and guarantees. The implementation of the Criminal Procedure Code has stated that pretrial functions are for the purpose of supervision of the protection of the rights of suspects in preliminary examinations of a criminal case, which in principle prioritizes giving protection to human rights since the Criminal Procedure Code also holds a principle of presumption of innocence which essentially states that no one can be found guilty as long as there is no permanent decision from a court hearing.
\end{abstract}

Keywords: corruption crimes, human rights, protection, suspects.

DOI: $10.7176 / \mathrm{JLPG} / 87-18$

Publication date:July $31^{\text {st }} 2019$

\section{Introduction}

Article 1 paragraph (3) of the 1945 Constitution of the Republic of Indonesia (UUD NRI 1945) explicitly asserts that Indonesia is a legal state. ${ }^{1}$ As a legal state, Indonesia upholds the law and the rule of law. This means that all state actions must be based on law and can be legally accounted for, to realize justice, rule of law, legal certainty and protection of human rights. The Indonesian state's commitment to guaranteeing legal protection and justice for citizens can be found in the views of national leaders as outlined in the Fourth Paragraph for the Opening of the 1945 Constitution of the Republic of Indonesia, which expressly states "then to form an Indonesian state government that protects the entire Indonesian nation and all of Indonesia's bloodshed and advancing public welfare, educating the life of the nation and participating in carrying out world order based on freedom, eternal peace and social justice

The commitment is then reinforced again in Article 28D paragraph (1) of the 1945 Constitution of the Republic of Indonesia which mandates that everyone has the right to recognition, guarantees, and fair legal certainty and equal treatment before the law. Law and human life are inseparable things. This was also expressed by Cicero as "the societas ibi ius", which means where there is a community, there is a law. Every human being must have interests that are expected to be fulfilled. Given the many interests, it is not impossible to have conflicts or clashes between humans, because their interests are in conflict.

The 1945 Constitution of the Republic of Indonesia in the Third Amendment of 2001 namely Article 1 paragraph (3) affirms that Indonesia is a country based on law (rechtstaat), not based on power (machtsstaat). ${ }^{2}$ Law has an important role in the life of society and the state to realize the ideals of the nation and state. Law enforcement is an absolute requirement for efforts to realize a peaceful and prosperous Indonesia. The absence of law enforcement will hinder the realization of a peaceful and prosperous society.

Moeljatno's formulation indicates that criminal law is a set of rules governing 3 elements, namely the rule of crime, criminal liability and the verbal process of law enforcement if a crime occurs. This element shows the relationship between material criminal law and formal criminal law, which means that violations of the material criminal law will have no meaning without the establishment of formal criminal law (criminal procedure law). Similarly, the formal criminal law cannot function without violating the norms of material criminal law (criminal acts). ${ }^{3}$ In its implementation, law enforcement is still far from the sense of justice expected by the community. The community considers that the state has not been able to guarantee justice and legal certainty equally for all its citizens, because there is still selective logging in the actions against criminals. From the reforms carried out

\footnotetext{
${ }^{1}$ According to Aristotle, the rule of law is a state that stands above the law that guarantees justice to its citizens. Justice is a condition for achieving the happiness of the lives of its citizens, as a basis for justice, it is necessary to teach morality to every human being. In a ruling country it is not a real human being, but a just mind, while the real ruler is only a law holder and balance.

${ }^{2}$ Haeranah, Ganti Kerugian Bagi Terangka, Terdakwa, Terpidana dalam Perspektif Hak Asasi dan Tanggung Jawab Negara, Pustaka Pena Press, Makassar, 2016, p. 1

${ }^{3}$ Andi Sofyan and Nur Azisa, Hukum Pidana, Makassar: Pustaka Pena Press, 2016, p. 3
} 
in the Criminal Procedure Code (KUHAP), there is concern and respect for human rights, because the criminal procedure law aims to (1) seek and obtain or at least approach material truth, is the truth as complete as possible from a criminal case by applying the provisions of criminal procedural law honestly and appropriately; (2) Finding the perpetrator of a criminal act and imposing a crime; and (3) Keeping those who are innocent, not convicted, even though the person has been accused of a criminal offense.

The pre-trial concept in Indonesia was inspired by commissioner judges in European countries. Basically, a pretrial application is submitted to the court, if there are rights violated. The right to file a pretrial is owned by a suspect or victim, his family, or other authorized parties, investigators and prosecutors, and third parties. Cases that can be applied for pretrial include whether or not the arrest and or detention is valid, whether or not the termination of the investigation or termination of the prosecution, the request for compensation and rehabilitation are valid or not. The judicial process in Indonesia is based on Pancasila, which places human dignity and dignity in its place and implements human rights protection and guarantees. The implementation of the Criminal Procedure Code has stated that pretrial functions are for the purpose of supervision of the protection of the rights of suspects in preliminary examinations of a criminal case, which in principle prioritizes giving protection to human rights since the Criminal Procedure Code also holds a principle of presumption of innocence which essentially states that no one can be found guilty as long as there is no permanent decision from a court hearing.

Changes that occur in the legal structure, especially with the establishment of a new institution automatically influence the social conditions by shifting patterns of thinking and behavior in society, there are two functions that can be carried out by law in society, namely as a means of control (a tool of social control) and as a means for social engineering (a tool of social engineering). ${ }^{1}$ Law enforcement is a series of activities in the implementation of applicable legal provisions, both in the form of action and prevention, covering all technical and administrative activities carried out by law enforcement officers, so as to create a safe, peaceful and orderly atmosphere to strengthen legal certainty in society. Law enforcement here is broadly interpreted not only by implementing criminal law but everywhere more than just the application of positive criminal law, namely not only regulating the actions of citizens in general but also regulating the authority of law enforcement officers.

The purpose and objective of the Pre-trial Institution is generally in accordance with the intent and purpose of the establishment of the Criminal Procedure Code with the aim of upholding the law, legal certainty and protection of the suspect's rights, because according to the Criminal Procedure Code each forced action must be in accordance with the provisions stipulated in the Criminal Procedure Code. Because every act of forced effort such as arrest, search, seizure, detention, prosecution and so on that is contrary to laws and regulations is an act of deprivation of human rights. The criminal acts of corruption that occurred in Indonesia became a separate threat for this nation to realize the national goals mandated in the Preamble of the 1945 Constitution. The rise in the practice of criminal acts of corruption in Indonesia will have an impact on the inhibition of national development programs aimed at prospering the entire community.

Corruption is very detrimental to the state on a very large scale. ${ }^{2}$ The characteristics of corruption are carried out systematically and have a widespread impact, placing corruption as an extraordinary crime. ${ }^{3}$ For this reason, efforts to tackle and eradicate corruption should be extraordinary, which is carried out in ways that are different from other crimes. Overcoming and eradicating extraordinary acts of corruption are carried out on the basis of the consequences of corruption.

Crime of corruption is not only detrimental to state finances and the country's economy, but also has the potential to damage the joints of social life and the economic rights of society at large. ${ }^{4}$ Law enforcement of criminal acts of corruption carried out by the Corruption Eradication Commission (KPK) can potentially cause problems regarding human rights violations in the event that a person is suspected of being a criminal act of corruption. In principle, the KPK has guidelines that must be adhered to in determining someone to be a suspect in a criminal act of corruption.

Montesquieu states that a good form of legislation must allow prevention of crime rather than punishment. ${ }^{5}$ The Criminal Procedure Code is expected to be a guideline for carrying out justice for courts in the general court and the Supreme Court by regulating rights and obligations for those in criminal proceedings, so that the basis of the rule of law can be enforced. ${ }^{6}$ The Criminal Procedure Code has provided guidance in determining someone

\footnotetext{
${ }^{1}$ Soerjono Soekanto, 1973, Pengantar Sosiologi Hukum, Jakarta, Bharata, p. 58

${ }^{2}$ Kadarudin, Asset Recovery Hasil Kejahatan Korupsi: Upaya Pengembalian Kerugian Keuangan Negara Melalui Kerjasama Internasional, Pustaka Pena Press, Makassar, 2015, p. 17

${ }^{3}$ Romli Atmasasmita, 2002, Korupsi, Good Governance \& Komisi Anti Korupsi di Indonesia, Badan Pembinaan Hukum Nasional, Departemen Kehakiman dan HAM RI, Jakarta, p. 9

${ }^{4}$ Mien Rukmini, 2014, Aspek Hukum Pidana dan Kriminologi: Sebuah Bunga Rampai, PT. Alumni, Bandung, p. 112-113

${ }^{5}$ Muhadar and Audyna Mayasari Muin, Kriminologi (Suatu Pengantar), Makassar: Pusat Kajian Media dan Sumber Belajar, LKPP Universitas Hasanuddin, 2016, p. 3; see also A.S. Alam, 2010, Pengantar Kriminologi, Makassar: Pustaka Refleksi Books, p. 10-11

${ }^{6}$ M. Said Karim, Ganti Kerugian Terhadap Korban Penangkapan yang Tidak Sah dalam Proses Peradilan Pidana, Pustaka Pena Press, Makassar, 2019, p. 1
} 
to be a suspect, which is based on preliminary evidence that sufficient specific provisions regarding sufficient initial evidence are not further stipulated in the Criminal Procedure Code, but are regulated in the KPK Law. Article 44 paragraph (2) of the Corruption Eradication Commission Law states that "sufficient preliminary evidence is deemed to have existed if at least 2 evidence has been found, including and not limited to information or data that is said, sent, received or stored ordinary or electronic or optical". Post-Decision of the Constitutional Court Number 21/PUU-XII/2014, April 28 has brought a new chapter in the process of enforcing criminal law. The decision of the Constitutional Court that granted the petition for judicial review of Article 77 letter a of the Criminal Procedure Code, in principle formed a new norm by extending the authority of PreJudicial Institutions including in examining the validity of the suspect's determination carried out by investigators in the investigation process.

The decision of the Constitutional Court which extends the pretrial authority including the object of the determination of the suspect, does not make the problem complete, it raises other problems, namely related to the application of evidence in the trial of pretrial applications with the object of the determination of the suspect. The fact shows that there is no understanding between the pretrial judges and the defendants in delivering the evidence that forms the basis of the determination of someone to be a suspect, where this fact occurs in the case of a pretrial petition Dahlan Iskan and Ilham Arief Sirajuddin. Based on the above, the problem that will be discussed in this paper is how is the protection of human rights for suspects of corruption? what is the value of justice for suspects of corruption? and what is the value of legal certainty for suspected corruption?

\section{Research Method}

This type of research is socio-juridical using a statute approach and a conceptual approach. ${ }^{1}$ The data used are primary data and secondary data collected through interviews and documentation studies. The collected data is then analyzed qualitatively then described.

\section{Results and Discussion}

\section{A. Human Rights Protection for the Suspects of Corruption}

Pancasila as the ideology and philosophy of the state is the basis in formulating the principles of legal protection and human rights in Indonesia. The concept of legal protection for the people is based on the concepts of recognition and protection of human rights and the concept of rechsstaat and the rule of law. According to Muhammad Basri, the concept of recognizing the protection of human rights provides its contents while, while the concept of rechsstaat and the rule of law creates its ingredients, thus the recognition and protection of human rights will flourish in rechsstaat and the rule of law. ${ }^{2}$

This pretrial effort is an ordinary legal event, but because those who apply for pre-trial are famous people, public officials, or important people in this country so that pretrial efforts become public attention, moreover the Corruption Eradication Commission institution that is the respondent in the pretrial case sought by a number of parties who have obtained the status of "suspect" by the anti-racial institution. ${ }^{3}$

The rights of citizens to obtain protection are positive rights which in the sense must be fulfilled actively and maximally by the state towards its citizens. ${ }^{4}$ Before the entry into force of the Criminal Procedure Code through Law No. 8 Year 1981, the criminal procedural law as a guideline for general justice is HIR Stb. Year 1941 Number 44 which is a colonial legal product with various aspects in its era, which has certain problems with good problems with its shortcomings and weaknesses, which basically benefit the authorities (invaders), and even those provisions deny protection of human rights, uncertainty law and justice. For example, according to Soeparmono, there is uncertainty about the preliminary actions in the legal process in terms of arrest, search, confiscation, detention, rights and status of suspects, defendants, legal assistance, length and uncertainty in the settlement process at all levels of examination and so on. ${ }^{5}$

With the enactment of Law No. 8 Year 1981, the protection of human rights is a major concern, this can be seen in the Consideration of the Law. In consideration, in particular letters a and c are explained, that (a) the Republic of Indonesia is a legal state based on the Pancasila and the 1945 Constitution of the Republic of Indonesia which upholds human rights and guarantees citizens together in law and government and must uphold the law and the government with no exceptions; and (c) The development of such national law in the field of criminal procedure law is so that the community lives its rights and obligations and to improve the development of attitudes of law enforcement officials in accordance with their respective functions and authorities in the

\footnotetext{
${ }^{1}$ Peter Mahmud Marzuki, 2005, Penelitian Hukum, Prenadamedia Group Jakarta, p. 35

${ }^{2}$ Muhammad Basri, 2018. Hakikat Tuntutan Ganti Rugi Pada Perkara Pidana, Dissertation, Fakultas Hukum, Universitas Hasanuddin, p. 82.

${ }^{3}$ Kadarudin, Menguak Sisi Lain dari Putusan Praperadilan Kasus Setya Novanto, Prosiding Seminar Nasional "Pra Peradilan dalam Kajian

Teori dan Praktik: Studi Putusan Kasus Setya Novanto, Sekolah Tinggi Ilmu Hukum Awang Long, Samarinda 5 November 2017, p. 60

${ }^{4}$ Nur Azisa, Nilai Keadilah Terhadap Jaminan Kompensasi Bagi Korban Kejahatan (Sebuah Kajian Filospfis - Normatif), Pustaka Pena Press, Makassar, 2016, p. 10

${ }^{5}$ R. Soeparmono, 2015. Praperadilan dan Penggabungan Perkara, Gugatan Ganti Kerugian dalam KUHAP, Mandar Maju, Bandung, p. 2
} 
direction of law enforcement, justice and protection of dignity and human dignity, order and legal certainty for the implementation of a state law in accordance with the 1945 Constitution.

In history, the emergence of pre-trial concepts cannot be separated from the long history of the need for rigorous judicial supervision (strict judicial security) against all acts of deprivation of one's civil liberties. This konjsep came to light the first time when the British sparked the Magna Charta in 1215 which was born as a critic of the King's arbitrariness at that time.

Although the birth of the Magna Charta concept was intended to limit the king's power, in it there was the idea that human rights were more important than the king's power. No citizen can be detained, or deprived of his property, or exiled or in any way, his rights are castrated except in legal considerations. This concept is then known as habeas corpus. Basically, the Criminal Procedure Code itself has laid the foundation for the relationship between KUHAP and human rights. One of the human rights is the rights owned by other people, including victims, in their efforts to ask for protection for themselves in court.

Furthermore, basically the Criminal Procedure Code relies on the concept of a legal state that contains universal joints, such as the recognition and protection of human rights, legality and state/government actions in the sense that the actions of state apparatus must be legally justified to ensure a free trial. Thus, the joints of the concept of the rule of law must be reflected in various fields of law, including criminal procedural law.

For the Indonesian people, human rights have been outlined in the Indonesian Constitution of the Republic of Indonesia, in 1945 which originates from the Pancasila as the nation's view of life. Thus, these principles must be set forth in particular legal principles related to criminal procedure regulation or KUHAP. These principles will become the guidelines of law enforcement officials and all citizens who are involved and interested in implementing a legal action related to the Criminal Procedure Code. ${ }^{1}$ That one of the pretrial institutions referred to in the pretrial understanding according to Article 10 letter a KUHAP. In Article 77 letter a KUHAP states: the district court has the authority to examine and decide, according to the provisions stipulated in this Law concerning the legality of the arrest, detention, termination of investigation or termination of prosecution.

Then by the Constitutional Court that the provisions of Article 77 letter a are deemed unable to fulfill the constitutional rights of each citizen, the Constitutional Court through its decision No. 21/PUU-XII/2014, in its legal norm states "because the determination of suspects is part of the investigation process constituting deprivation of human rights, then the determination of suspects by investigators is an object that can be requested for protection through the pretrial legal institution the inclusion of the validity of the determination of suspects as objects of pretrial institutions so that the treatment of a person in the criminal process considers suspects as human beings who have dignity and dignity. the same position before the law". 2

After the Constitutional Speech Decision Number 21/PUU-XII/2014 certainly has its own legal consequences, especially in terms of protection for suspects. Further, the reason for the Constitutional Court Decision Number 21/PUU-XII/2014 has the spirit of achieving enforcement, protection and respect for Human Rights. The Constitutional Court realistically considers that the KUHAP which was ratified in the previous era (in 1981) as the legal basis for proceedings in the Criminal realm, is considered to be less relevant to the development of Indonesian criminal law today. Particularly in the article relating to the embodiment of Human Rights for suspects, who are considered lacking protection and respect in the Criminal Procedure Code. ${ }^{3}$

In its consideration, the Constitutional Court stated that Indonesia was a legal state. In a state of law, the principle of due process of law as one of the manifestations of recognition of human rights in the criminal justice process becomes a principle that must be upheld by all parties, especially by law enforcement agencies. The realization of the human rights award is carried out by providing a balanced position based on the applicable legal rules, including in the judicial process, especially for suspects, defendants and prisoners in maintaining their rights in a balanced manner. Therefore, the state, especially the government, is obliged to provide protection, promotion, enforcement and fulfillment of human rights, the Criminal Procedure Code as formal law in the Indonesian criminal justice process has formulated a number of suspect rights as protection against possible human rights violations.

The Indonesian Constitution, Article 28I of the 1945 Constitution proves the Indonesian state's recognition of the existence of human rights in Indonesia, which fully determines that "To uphold and protect human rights in accordance with the principles of a democratic rule of law, the implementation of guaranteed rights is regulated. and set out in legislation". Further, Article 28D paragraph (1) of the 1945 Constitution stipulates that "Every person has the right to the recognition, guarantee, and fair legal certainty and equal treatment before the law".

Based on the Constitution, the Indonesian Government must provide protection for human rights, even if the person has a status as a suspect. This is a logical consequence because Indonesia is a legal state that upholds human rights. The obligation for the protection of human rights applies to all citizens of Indonesia, regardless of

\footnotetext{
${ }^{1}$ R. Soeparmono, Ibid., p. 70

${ }^{2}$ Bagian (1.16) angka huruf k p. 105-106.

${ }^{3}$ http://www.hukumpedia.com/twtoha/pra-peradilan hukum pedia site, accessed October 7, 2017
} 
whether the citizen is not a suspect or if the citizen is subject to suspect status. Thus, regardless of whether the suspect is "suspected" of committing a criminal offense, still in the suspect there are still "Human Rights" which must obtain legal certainty and guarantee in every legal process that the suspect receives.

The form of human rights protection for suspects in Indonesian law is contained in the Indonesian Criminal Procedure Code. The main essence of the enforcement of the Criminal Procedure Code is to protect citizens from arbitrary acts carried out by law enforcement officers (police, prosecutors, KPK, civil servant investigators, etc.). The protection measures for human rights (Prevention of arbitrary treatment from the state apparatus) are manifested by the Criminal Procedure Code through the pretrial institution.

In the Pre-trial Institution it is possible for the suspect to sue state law enforcement officers who are considered arbitrary. This condition is certainly not separated from the process of the birth of a pretrial institution which was considered the masterpiece of the KUHAP in its time, because pretrial accommodated the interests of human rights in the criminal law. On his journey in Indonesia, the application of the Criminal Procedure Code has expanded the object of pretrial after a request for a Test of Material on the Criminal Procedure Code conducted by Bachtiar Abdul Fatah. Before the existence of the Supreme Court decision, the stipulation of Article 77 of the Criminal Procedure Code which regulates the Pre-trial Institution determines Article 77 letter a: the legality or failure of arrest, detention, termination of investigation or termination of prosecution. Article 77 letter b: compensation and/or rehabilitation for a person whose criminal case is terminated at the level of investigation or prosecution. However, after the decision of the Constitutional Court, the provisions of Article 77 letter a are added with the authority to test the validity of a suspect's determination. A number of arguments put forward by Bachtiar Abdul Fatah in the application for the Test of Material Law on the Criminal Procedure Code, namely that the provisions of Article 77 of the Criminal Procedure Code are considered contrary to Article 28D and Article 28I of the 1945 Constitution on Human Rights. Complete Article 28I of the 1945 Constitution stipulates "To uphold and protect human rights in accordance with the principles of a democratic legal state, the implementation of human rights is guaranteed, regulated, and set forth in laws and regulations".

\section{B. Justice Value for the Suspects of Corruption}

Law gives the constitutional right to everyone to be free from the treatment of degrading honor and dignity, which should not be taken arbitrarily by anyone. Implementation of Indonesian state law at the state level that the highest law is the constitution. Therefore, every act of state administrator, the government and all state equipment, including law enforcement officials, must be based on applicable laws to realize social order and legal certainty and justice.

According to Soekarno Aburaera et.al. Law and justice are two interlocking elements which are "condotio sine qua non", law is an external manifestation of justice, and justice is internal and the essence of spirit is a form of law. So that the rule of law (supremacy of law) is supremacy of juctice as well as vice versa, both are commutative things. The law is not in the absolute dimension of the law, but the law is in the dimension of absolute justice. The law will not be able to survive if the spirit of justice has been lost. As a result, the distortion of legal thinking with the loss of legal integrity has caused the law to be unable to become a means of justice products, the component of the legal apparatus has not been able to produce justice (jusctice producer), because legislators are unable to deliver justice as a legislative spirit, or enforcer the law itself does not have high moral integrity. ${ }^{1}$

According to Gustav Radbruch, law embodies one of the values in human concrete life. That value is the value of justice, the law only means as a law if the law is an embodiment of the value of justice, and at least is an effort towards it. ${ }^{2}$ Radbruch further said that justice is a law only means as a law if the law is an embodiment of the value of justice, and at least it is an effort in that direction. Justice must meet formal legal regulations, human rights that must not be violated or must be recognized. Third, that there must be a balance between violation and punishment. ${ }^{3}$ In fact, pretrial institutions can be stated as an attempt to correct irregularities that occur during the investigation and prosecution process. Thus, the existence of pretrial provisions in the Criminal Procedure Code is a demand for officials involved in the process of investigation, prosecution, in addition to running their tuition in a professional manner for the sake of upholding the rule of law, also guaranteeing security for the public.

Justice not only provides equal punishment for violators, but also includes giving equal treatment before the law between citizens who violate the law. Injustice in law enforcement is more heartbreaking and destroys people's hopes for justice. Pre-trial practice related to the determination of suspects, initially can be found in Decision Number 38/Pid.Prap/2012/PN.Jakarta.Selatan. The legal considerations are to connect the validity of the determination of the suspect with detention as a forced effort and then interpret the meaning of sufficient evidence in the provisions of Article 21 paragraph (1) of the Criminal Procedure Code to the provisions of

\footnotetext{
${ }^{1}$ Sukarno Aburaiea, et.al., 2010. Filsafat Hukum, Dari Rekonstruksi Sabda Manusia dan Pengetahuan Hingga Keadilan dan Kebenaran. Penerbit Pustaka Refleksi, Makasssar, p, 70.

2 Theo Huijbers OSC., 1982. Filsafat Hukum dalam Lintasan Sejarah, Yayasan Kanisius, Yogyakarta, p. 174

${ }^{3}$ Ibid.
} 
Article 184 paragraph (1). part of the determination of suspects is considered not pre-trial material.

In its development, through the Decision of Constitutional Court Number 21/PUUXII/2014, pretrial objects become (a) legal or not validation, the determination of suspects, confiscation, detention, termination of prosecution; and (b) compensation and/or rehabilitation for a person whose criminal case is stopped at the level of investigation or determination.

The next practice is known through Decision Number 04/Pid.Prap/2015/PN.Jkt.Sel. In considering its decision, the investigator's authority is tested against the position of the suspect as a law enforcer or state administrator or not both. The ruling stated that the Investigation Order which stipulated the Petitioner as a Suspect by the Respondent was invalid and was not based on the law, and therefore the Determination of $a$ quo had no binding power.

A pretrial institution can be seen as an imitation of a judge commissioner (rechter commissaris) institution in the Netherlands and Judge and Instruction in France, but pre-trial duties and functions in Indonesia are different from Judicial Commissioners in Europe, including in the Netherlands and France. The duties of commissioner judges in the Netherlands are broader than the pretrial duties and functions in Indonesia. ${ }^{1}$ The judge who presides over the preliminary examination within the board of commissioner judges, this appears as a manifestation of the activist's judge. For example, in Central Europe the authorities are active in handling forced efforts (dwang middelen), detention, confiscation, searches of bodies and homes, and examination of letters. ${ }^{2}$ If it is observed that the provisions of the KUHAP governing pretrial institutions in Indonesia do not regulate the authority as broad as the authority of the commissioning judge in the Netherlands. In order to give justice to justice seekers, the authority of pretrial institutions in Indonesia must also be the same as the authority of the commissioner judge. So that in addition to for example the authority to judge the legality of an arrest, detention as mentioned in Article 77 of the Criminal Procedure Code, also must be authorized to assess the legitimacy of a seizure, a search carried out by both the police and prosecutors.

Thus, the scope of pretrial is actually limited in the provisions of Article 77 of the Criminal Procedure Code, but it turns out that the development of criminal law after Judge Sarpin's pre-trial decision on a pretrial petition petitioned by Budi Gunawan has broken through these boundaries and even preceded the discussion of the draft Criminal Procedure Code. Legal development is a tangible manifestation of the implementation of a resposive theory that describes law as a means of responding to social provisions and aspirations of the community. The expansion of the scope of pretrial, especially regarding the determination of suspects has been initiated before the ruling of the Constitutional Court Number 21/PUU-XII/2014 was issued.

One of the pillars or demands for reform is the occurrence of consistent law enforcement and not being coopted by power. Because, the law enforcement process, in fact does not only occur at the stage of application/law enforcement, but can begin at the formulation stage (the stage of law making). According to Satjipto Rahardjo, legal thinking needs to go back to its basic philosophy, namely law for humans. ${ }^{3}$ With this philosophy, humans become determinants and points of legal orientation. Law is in charge of serving humans, not vice versa. Therefore, the law is not an institution that is free from human interests. The quality of law is determined by its ability to serve human welfare. This causes progressive law to adhere to the ideology of "pro-justice and propeople. ${ }^{4}$

Law enforcement is a series of activities in the effort to implement applicable legal provisions that are both legal and preventive in nature covering all technical and administrative activities carried out by law enforcement officers, so that they can create a safe, peaceful and orderly atmosphere for the sake of stabilizing certainty. law in society. as according to the ethical theory of law is solely aimed at justice. The contents of the law are determined by our ethical beliefs about fair and not. In other words, the law according to this theory aims to realize or realize justice.

Law enforcement here is broadly interpreted not only by implementing criminal law but is interpreted more than just the application of positive criminal law, namely not only regulating the actions of citizens in general but also regulating the authority/power of law enforcement officers. Bernard Arief Sidharta, who stated that the determination of suspects was the result of investigation, as can be seen from the meaning of "investigation" in Article 1 point 2 of the Criminal Procedure Code which reads "investigation is a series of investigative actions in terms of and according to the method stipulated in this law to search for and collect evidence with evidence that makes clear about the crime that occurred and to find the suspect".

Based on the understanding of the investigation that determining a person to be a suspect is a legal decision taken by the Investigator in the stage or process of investigation by first seeking and collecting evidence and with evidence that makes clear about the crime that occurred. Protection of Human Rights is a very broad term.

\footnotetext{
${ }^{1}$ Andi Hamzah, 1985. Pengantar Hukum Acara Pidana Indonesia, Balai Aksara, Jakarta, p. 188

${ }^{2}$ Oemar Seno Adji, 1980. Hukum, Hakim Pudana, Erlangga, Jakarta, p. 88

${ }^{3}$ Dalam Yohannes Suhardin, Fenomena Mengabiakan Keadilan Dalam Penegakan Hukum, Jurnal Mimbar Hukum, Volume, 21, Nomor 2, p. 346

${ }^{4}$ Ibid.
} 
Law Number 39 Year 1999 concerning Human Rights does not provide a complete interpretation of the term of protection. Explanation of the Law on Human Rights, specifically the explanation of Article 8 only states what is meant by "protection" is including the defense of human rights.

The purpose and purpose of holding a pretrial institution is generally in accordance with the intent and purpose of the establishment of the Criminal Procedure Code with the aim of upholding the law, legal certainty and protecting the rights of suspects, because according to the KUHAP system each forced action must be in accordance with the provisions of the Criminal Procedure Code. Because every act of forced effort such as arrest, search, seizure, detention, prosecution and so on which is contrary to law and legislation is an act of rape or deprivation of human rights.

Satjipto Rahardjo places more emphasis on the moral modalities of law enforcers in defending the interests of vulnerable people through improvisation by presenting a sense of social justice. Therefore, Satjipto Rahardjo said that "Progressive law elevates the human factors of law enforcement as an important determinant in the course of the law. Progressive law does not see the way of law as 'flat', but contains a strong modality. These modalities are compassion, empathy, sincerety and dare. As a consequence of the paradigm 'law for humans", then law enforcement must not be flat, but full of conscience involvement to protect and serve humans.

\section{Legal Certainty Value for the Suspects of Corruption}

Law has an important role in the life of society and the state to realize the ideals of the nation and state. Since the role of law is very important, the Indonesian state expressly states that Indonesia is a country based on law. This is stated in Article 1 paragraph (3) of Chapter I of the Third Amendment of the 1945 Constitution of the Republic of Indonesia which confirms that the Indonesian state is a legal state. That is, the unitary state of the Republic of Indonesia is a state based on law (recsstaat), not based on mere power, and a government based on a constitutional system (basic law) and not absolutism (unlimited power). As a consequence of Article 1 paragraph (3) of the Third Amendment to the 1945 Constitution of the Republic of Indonesia, three basic principles must be implemented, namely the rule of law, equality before the law and law enforcement in ways that do not conflict with the law. This is an effort to realize legal certainty.

A legal state according to Sri Soemantri, must fulfill several elements, namely (1) the government in carrying out its duties and obligations must be based on law or legislation; (2) guarantee of human rights (citizens); (3) the division of power within the state; and (4) supervision from judicial bodies. ${ }^{2}$ Based on the above, then in the Indonesian law as an effort to enforce the law especially against criminal acts of corruption, it cannot ignore the basic purpose of the law itself, one of which is legal certainty.

The concept of pretrial is actually limited in the provisions of Article 77 of the Criminal Procedure Code, but it turns out that the legal development of the last 5 years has broken through these boundaries and even preceded the discussion of the draft Criminal Procedure Code. Legal development is a tangible manifestation of the implementation of a resposive theory that describes law as a means of responding to social provisions and aspirations of the community. The expansion of the scope of pretrial, especially regarding the determination of suspects has been initiated before the ruling of the Constitutional Court Number 21/PUU-XII/2014 was issued.

Pre-trial practice related to the determination of a suspect, initially can be found in Decision Number 38/Pid.Prap/2012/PN.Jkt.Sel. The legal considerations are to connect the validity of the determination of the suspect with detention as a forced effort and then interpret the meaning of sufficient evidence in the provisions of Article 21 paragraph (1) of the Criminal Procedure Code to the provisions of Article 184 paragraph (1). part of the determination of suspects is considered not pretrial material.

The next practice is known through Decision Number 04/Pid.Prap/2015/PN.Jkt.Sel. In considering its decision, the investigator's authority is tested against the position of the suspect as a law enforcer or state administrator or not both. The ruling stated that the Investigation Order stipulating the Petitioner as a Suspect by the Respondent was invalid and not based on law, and therefore the determination of aquo did not have binding power.

It was realized that after the Constitutional Court Decision Number 21/PUU-XII/2014, it was decided that the provisions of Article 77 letter A of the Criminal Procedure Code do not have binding legal force insofar as they are not interpreted including the determination of suspects, searches and seizures. As for one of the legal considerations, the determination of suspects is part of the investigation process which is the deprivation of human rights, so that the determination of the suspect by the investigator is an object that can be requested for protection through the pretrial legal procedure. This is solely to protect someone from arbitrary acts of investigators which are likely to occur when a person is named a suspect, even though there is a mistake in the process, there is no other institution other than a pretrial institution that can examine and decide.

The Constitutional Court ruling provides protection for someone who has gone through a wrong legal

${ }^{1}$ Dalam Shidarta, ed, Konsorsium Hukum Progresif, 2013, Dekonstruksi dan Gerakan Pemikiran Hukum Progresif, Judul: Pendekatan Hukum Progresif Dalam mencairkan Kebekuan Produk Legislasi, (Yogyakarta, Thafa Media, 2013), p. vii-viii

${ }^{2}$ Sri Soemantri, dalam Rukmini, 2003. Perlindungan Hak Asazi Manusia Melalui Asas Praduga tak bersalah dan Asas Persamaan Kedudukan Dalam Hukium pada Sistem Peradilan Pidana Indonesia, Alumni, Bandung, p. 1 
process when he is named a suspect. In the provisions of Article 8 of Law Number 39 Year 1999 concerning Human Rights, it is regulated that "Protection, promotion, enforcement and fulfillment of human rights are primarily the responsibility of the government. This means that the Constitutional Court takes a role in fulfilling human rights through its decisions as part of constitutional responsive efforts. One element of legal protection emphasized through this decision is legal certainty that investigators must carry out investigative actions in accordance with applicable legal procedures.

After the Constitutional Court Decision was born, the pretrial application for the determination of the suspect has a legal basis to be brought to court but there are special characteristics of pretrial filing related to the determination of the suspect, namely 1). conducted after the determination of the suspect so that 2 evidence are not fulfilled. 2). The second pretrial application regarding the determination of the suspect cannot be categorized as ne bis in idem because it does not involve the case, 3 ). other suspects in different files are invalid.

The Constitutional Court through Decision Number 109/PUU-XIII/2015 interpreted the meaning of the KPK's independent investigator as the reason for filing a pretrial application that was illegal in the determination of the suspect. The Constitutional Court considered, that when there was a difference between Law Number 30 Year 2002 and the Criminal Procedure Code regarding the position of investigators, then in carrying out its duties the KPK remained bound to Law Number 30 Year 2002 and could override the KUHAP as long as it was specifically regulated in Law Number 30 Year 2002, in line with the lex principle specialis derogat legi generalis. Furthermore, the Court is of the opinion that KPK investigators as stipulated in Article 45 paragraph (1) of Law Number 30 Year 2002 do not only have to come from the police institution as stipulated in Article 6 paragraph (1) of the Criminal Procedure Code and according to the Court, the KPK has the authority to appoint its investigators.

Through this ruling, the Constitutional Court affirmed its position as the interpreter of the law by connecting through systematic interpretation of the principle of the specificity of a law. To create consistency of attitudes towards the content of the interpretation of the Constitutional Court, the KPK's independent investigators have not existed to be made part of the pretrial application for the determination of suspects. Unity of law needs to be built to avoid abuse of power for certain interests.

Efforts to correct the investigative actions, especially related to efforts to fulfill justice in the determination of the judiciary, can be seen in the statement of the pretrial Judge number 24/Pid/Pra/2018/PN.Jkt.Sel, Effendi Mukhtar has used a choice of sentences and fine language in its consideration that it should be able to penetrate the heart of law enforcement agencies and institutions with the sentence "... Instead of the KPK being sued repeatedly and always answering with the same answer that the KPK is still continuing to explore and collect evidence and because the KPK cannot issue termination letters the investigations whose time is unclear, and which until now has been three years since Budi Mulya's case has a permanent legal force, will be more honorable and elegant if the KPK delegates the case to the public prosecutor or the police ... ". Thus, subtle criticism delivered by pretrial judges for the sake of realizing overall justice, borrowing the term judge, total justice, namely the investigator must consider a sense of justice in making decisions regarding the determination of suspects.

\section{Conclusion}

In the Pre-trial Institution it is possible for the suspect to sue state law enforcement officers who are considered arbitrary. The stipulation of Law No. 8 Year 1981 concerning the Criminal Procedure Code, the protection of human rights is a major concern. After the Constitutional Court Decision Number 21/PUU-XII/2014 was born, pretrial applications for the determination of suspects have a legal basis to be brought to court but there are special characteristics of pretrial submissions related to the determination of suspects, namely 1). suspects, searches, and seizures are carried out after the determination of the suspect so that 2 evidence are not fulfilled. 2). The second pretrial application regarding the determination of suspects cannot be categorized as ne bis in idem because it does not involve the case, 3). suspects on the basis of the results of the development of investigations of other suspects in different files is invalid. Through this ruling, the Constitutional Court affirmed its position as the interpreter of the law by connecting through systematic interpretation of the principle of the specificity of a law. To create consistency of attitudes towards the content of the interpretation of the Constitutional Court, the KPK's independent investigators have not existed to be made part of the pretrial application for the determination of suspects. Unity of law needs to be built to avoid abuse of power for certain interests.

\section{References}

A.S. Alam, 2010, Pengantar Kriminologi, Makassar: Pustaka Refleksi Books.

Andi Hamzah, 1985. Pengantar Hukum Acara Pidana Indonesia, Balai Aksara, Jakarta.

Andi Sofyan dan Nur Azisa, Hukum Pidana, Makassar: Pustaka Pena Press, 2016.

Haeranah, Ganti Kerugian Bagi Terangka, Terdakwa, Terpidana dalam Perspektif Hak Asasi dan Tanggung Jawab Negara, Pustaka Pena Press, Makassar, 2016. 
http://www.hukumpedia.com/twtoha/pra-peradilan hukum pedia site, accessed October 7, 2017

Kadarudin, Asset Recovery Hasil Kejahatan Korupsi: Upaya Pengembalian Kerugian Keuangan Negara Melalui Kerjasama Internasional, Pustaka Pena Press, Makassar, 2015.

Kadarudin, Menguak Sisi Lain dari Putusan Praperadilan Kasus Setya Novanto, Prosiding Seminar Nasional "Pra Peradilan dalam Kajian Teori dan Praktik: Studi Putusan Kasus Setya Novanto, Sekolah Tinggi Ilmu Hukum Awang Long, Samarinda 5 November 2017.

M. Said Karim, Ganti Kerugian Terhadap Korban Penangkapan yang Tidak Sah dalam Proses Peradilan Pidana, Pustaka Pena Press, Makassar, 2019.

Mien Rukmini, 2014, Aspek Hukum Pidana dan Kriminologi: Sebuah Bunga Rampai, PT. Alumni, Bandung.

Muhadar dan Audyna Mayasari Muin, Kriminologi (Suatu Pengantar), Makassar: Pusat Kajian Media dan Sumber Belajar, LKPP Universitas Hasanuddin, 2016.

Muhammad Basri, 2018. Hakikat Tuntutan Ganti Rugi Pada Perkara Pidana, Disetasi, Fakultas Hukum, Universitas Hasanuddin.

Nur Azisa, Nilai Keadilah Terhadap Jaminan Kompensasi Bagi Korban Kejahatan (Sebuah Kajian Filospfis Normatif), Pustaka Pena Press, Makassar, 2016.

Oemar Seno Adji, 1980. Hukum, Hakim Pudana, Erlangga, Jakarta.

Peter Mahmud Marzuki, 2005, Penelitian Hukum, Prenadamedia Group Jakarta.

R. Soeparmono, 2015. Praperadilan dan Penggabungan Perkara, Gugatan Ganti Kerugian dalam KUHAP, Mandar Maju, Bandung.

Romli Atmasasmita, 2002, Korupsi, Good Governance \& Komisi Anti Korupsi di Indonesia, Badan Pembinaan Hukum Nasional, Departemen Kehakiman dan HAM RI, Jakarta.

Shidarta, ed, Konsorsium Hukum Progresif, 2013, Dekonstruksi dan Gerakan Pemikiran Hukum Progresif, Judul: Pendekatan Hukum Progresif Dalam mencairkan Kebekuan Produk Legislasi, (Yogyakarta, Thafa Media, 2013).

Soerjono Soekanto, 1973, Pengantar Sosiologi Hukum, Jakarta, Bharata.

Sri Soemantri, dalam Rukmini, 2003. Perlindungan Hak Asazi Manusia Melalui Asas Praduga tak bersalah dan Asas Persamaan Kedudukan Dalam Hukium pada Sistem Peradilan Pidana Indonesia, Alumni, Bandung.

Sukarno Aburaera, et.al., 2010. Filsafat Hukum, Dari Rekonstruksi Sabda Manusia dan Pengetahuan Hingga Keadilan dan Kebenaran. Penerbit Pustaka Refleksi, Makasssar.

Theo Huijbers OSC., 1982. Filsafat Hukum dalam Lintasan Sejarah, Yayasan Kanisius, Yogyakarta. 